\title{
STORAGE IN CERRADO SOIL AND GERMINATION OF Psychotria vellosiana (RUBIACEAE) SEEDS
}

\author{
ARAÚJO, C. G. and CARDOSO, V. J. M. \\ Departamento de Botânica, Instituto de Biociências, Universidade Estadual Paulista Julio de Mesquita Filho, \\ C. P. 199, CEP 13506-900, Rio Claro, SP, Brazil \\ Correspondence to: Victor José Mendes Cardoso, Departamento de Botânica, Instituto de Biociências, \\ Universidade Estadual Paulista Julio de Mesquita Filho, C. P. 199, CEP 13506-900, \\ Rio Claro, SP, Brazil, e-mail: victorjc@rc.unesp.br \\ Received July 1, 2004 - Accepted October 13, 2004 - Distributed May 31, 2006
}

(With 3 figures)

\begin{abstract}
The regeneration of plant communities from seed depends, to a large extent, on the capacity of the seed remaining viable in the soil. The viability and germination of artificially buried Psychotria vellosiana seeds in cerrado soil were studied, with the purpose of discovering some physio-ecological aspects of dispersed seeds and evaluating their potential to constitute a soil seed bank. Seed samples were placed in nylon envelopes and buried in the soil of a Cerrado reserve at two different depths and sites. Buried seeds were retrieved periodically and tested for germination along with dry-stored seeds. In general, there was a reduction in seed germination with storage time, both in soil and dry stored conditions, and in some assays exhumed seeds germinated faster than dry stored ones. In general the soil storage favoured seed viability of ungerminated seeds as compared to dry stored ones, with the seeds remaining partially viable after 10 months of storage. The lack of germination of viable seeds suggests that seeds showed true dormancy and/or required an extended time to germinate. It was observed that some seeds had germinated while buried and such in situ germination tended to increase with rainfall. The water availability in the soil might be a limiting factor for successful germination of $P$. vellosiana in the field, and the seeds may constitute a persistent soil seed bank in the cerrado as dispersed seeds remain viable in the soil until the following period of seed dispersal.
\end{abstract}

Keywords: Psychotria vellosiana, dormancy, physio-ecology, dispersal units.

\section{RESUMO}

\section{Armazenamento em solo de cerrado e germinação de sementes de Psychotria vellosiana (Rubiaceae)}

A regeneração de comunidades vegetais depende em grande parte da capacidade das sementes de se conservarem viáveis no solo. Estudou-se a viabilidade e germinação de sementes de Psychotria vellosiana manualmente enterradas no cerrado, com o objetivo de se conhecer alguns aspectos fisio-ecológicos de sementes dispersas, bem como seu potencial em formar banco de sementes no solo. Amostras de sementes foram colocadas em invólucros de tela de nylon e enterradas no solo do cerrado, em duas profundidades e em dois ambientes diferentes. As sementes enterradas eram periodicamente recuperadas e testadas quanto à sua germinação, juntamente com sementes armazenadas a seco. Em geral houve uma redução da germinação em função do tempo de armazenamento, seja no solo, seja na estocagem a seco, e em alguns ensaios as sementes exumadas germinaram mais rapidamente do que as armazenadas a seco. Em geral o armazenamento no solo favoreceu a viabilidade de sementes não germinadas, em comparação com as armazenadas a seco, e as sementes conservaram-se viáveis por mais de dez meses. A não germinação de sementes viáveis sugere a ocorrência de dormência e/ou a necessidade de um tempo maior de germinação. Constatou-se que parte das sementes germinou enquanto estavam enterradas, sendo maior a ocorrência no período mais chuvoso. A disponibilidade de água no solo pode ser um fator limitante para a germinação no 
campo de $P$. vellosiana, e as sementes podem constituir um banco de sementes persistente, já que sementes dispersas conservaram-se viáveis até o próximo período de dispersão.

Palavras-chave: Psychotria vellosiana, dormência, fisio-ecologia, unidades de dispersão.

\section{INTRODUCTION}

The cerrado is the Brazilian savanna vegetation and it encompasses a core area in Central Brazil (most of Mato Grosso, Mato Grosso do Sul and Tocantins; Goiás; western Minas Gerais and Bahia) and the peripheral areas distributed throughout north Brazil, northern and south (small parts of São Paulo and Paraná), and extending to Bolívia and Paraguai (Ferri, 1977; Ratter et al., 1997). The cerrado is very varied in form, ranging from dense grassland, generally with a sparse covering of shrubs and small trees ("campo cerrado"), to almost close woodland with a canopy height of 12-15 m ("cerradão) (Ratter et al., 1997). The cerrado climate is defined by a strong dry season during the winter (nearly from April to September). Since seedlings are very sensitive to water stress, one supposed that the cerrado climate was a limiting factor for sexual reproduction of cerrado species, favouring vegetative propagation. However, it has been shown that sexual reproduction and seedling establishment are common features in the cerrado and involve adaptation mechanisms to this environment (Oliveira, 1998). For example, Labouriau et al. (1964) reported seeing seedlings of a number of species in cerrado vegetation in São Paulo, Minas Gerais and Goias. The authors express the need for more research on seed biology of cerrado species to acquire more general ecological propositions in the cerrado vegetation.

Regenerating plant communities from seed depends, to a large extent, on the capacity of the seed to germinate and establish seedlings under favourable conditions. Reserves of buried, viable seeds have been found in many habitats, constituting the soil seed banks. Two main types of seed banks are described: a transient seed bank, where none of the seeds persist for more than 1 year; and a persistent seed bank, where most of the seeds have extended viability in the soil (often many years) (Baskin \& Baskin, 1998). In a more functional approach, a persistent seed bank is defined as seeds that live until the subsequent germination season (Baskin \& Baskin, 1998). In general, seeds capable of forming persistent seed banks have dormancy mechanisms through which germination is arrested even the environmental conditions seems to be suitable for embryo growth (Bewley \& Black, 1994). According to Baskin \& Baskin (1998), a way to determine seed longevity in the soil is to sow seeds in the field and sample over a period of time to seed viability tests.

Psychotria vellosiana Benth. (Rubiaceae) is a bushy shrub or small tree, 2.5 to $4 \mathrm{~m}$ tall, common in shaded sites and distributed in eastern Brazil from Santa Catarina to Pernambuco, occurring in ombrophyllous forests, moist tropical forest and dense cerrado (cerradão vegetation). Taking into account that natural seed burial is possible in cerrado vegetation (Labouriau et al., 1964), the objective of this work is the viability assessment of artificially buried seeds of Psychotria vellosiana in cerrado soil as compared to dry stored seeds at room conditions, with the main purpose of evaluating whether dispersed seeds can constitute a soil seed bank.

\section{MATERIAL AND METHODS}

Psychotria vellosiana Benth fruit are two-seeded spherical drupoid. The seeds are convex and longitudinally sulcate on the dorsal side, with non-deep grooves on the flat ventral side (Barroso et al., 1999). Fruits were collected during the peak fruit period of the species from individuals growing along a trail in the Cerrado Reserve in April - May, 2001.

The Cerrado Reserve is in Corumbataí, São Paulo state $\left(22^{\circ} 15^{\prime} \mathrm{S}\right.$ and $\left.47^{\circ} 00^{\prime} \mathrm{W}\right)$ and consists of 38.7 ha of cerrado with elevations ranging from 800 to $830 \mathrm{~m}$ and a relatively high diversity of species for a marginal area with several species typical of forest formations (Cesar et al. 1988). The Reserve has been preserved from fire for the last fifty years.

Collections were carried out weekly until the number of fruit was sufficient for the assays, then seeds were removed and exposed to air on filter paper sheets until they were dry, and stored in 
paper bags at room temperature $\left(18\right.$ to $\left.27^{\circ} \mathrm{C}\right)$. One hundred seeds were individually weighed to the nearest milligram using analytical scales and the distribution of fresh mass classes was determined. Seed water content was calculated on a fresh weight basis and dry weight was obtained after drying five samples (50 seeds per sample) at $105^{\circ} \mathrm{C}$ for $24 \mathrm{~h}$. For viability tests, the seeds were submerged in a $3 \%$ tetrazolium chloride solution at $30{ }^{\circ} \mathrm{C}$ for $24 \mathrm{~h}$ and the stained seed counted. Imbibition of water by seeds was tested for intactness and scarified. Three samples of 50 seeds per sample were immersed in distilled water at $25^{\circ} \mathrm{C}$ and daily readings of sample weight were taken up to six days. Furthermore, the percentage of water uptake was calculated. Scarified seeds were obtained by friction of the seeds on sandpaper sheets.

The field experiments were done in the same Cerrado area where fruit was collected. Samples of 30 seeds were placed in $25 \mathrm{~cm} \times 12 \mathrm{~cm}$ fine-mesh nylon envelopes, the mesh being small enough to retain the seeds. The envelopes were buried at the depths of $5 \mathrm{~cm}$ and $15 \mathrm{~cm}$ in the cerrado soil, in two different sites: a shaded site, under a canopy; and an open site, where the canopy was lower and less dense. The burial assays started on May $25^{\text {th }}$, 2001 and were carried out in triplicate arranged as a factorial in a randomised block design. The chemical and physical analyses of the soil from the burial sites are presented in Table 1. Rainfall data were obtained from CEAPLA - IGCE -UNESP.

Germination assays were carried out on dry stored seeds and on seeds exhumed at approximately 30 day intervals from June $27^{\text {th }}, 2001$ to April $2^{\text {nd }}$, 2002, according to the Table 2.

At the time of seed burial, similar samples of seeds were placed in paper bags and stored in a laboratory at room conditions $\left(18\right.$ to $27^{\circ} \mathrm{C}$ ). When a seed sample was recovered from the soil, dry stored seeds were also removed from the bags and tested for germination under the same conditions as those used for seeds recovered from burial.

TABLE 1

Chemical analysis of soil from the Cerrado Reserve of Corumbataí, SP carried out by Centro de Ciências Agrárias - Universidade Federal de São Carlos - SP.

\begin{tabular}{|c|c|c|c|c|c|c|c|c|c|c|}
\hline \multirow[t]{2}{*}{ Site } & \multirow{2}{*}{$\begin{array}{c}\text { Depth } \\
\text { (cm) }\end{array}$} & \multirow{2}{*}{$\begin{array}{c}\mathbf{P} \\
(\mathbf{m g . d m}\end{array}$} & \multirow{2}{*}{$\begin{array}{c}\mathbf{O M} \\
\left(\text { g.dm }^{-3}\right)\end{array}$} & \multirow{2}{*}{$\begin{array}{c}\mathbf{p H} \\
\left(\mathrm{CaCl}_{2}\right)\end{array}$} & \multirow{2}{*}{$\begin{array}{c}\mathbf{N} \\
(\mathbf{p p m})\end{array}$} & $\mathbf{K}$ & $\mathbf{C a}^{2+}$ & $\mathbf{M g}^{2+}$ & $\mathbf{H}+\mathbf{A l}$ & $\mathbf{A \mathbf { l } ^ { 3 + }}$ \\
\hline & & & & & & \multicolumn{5}{|c|}{$\left(\mathbf{m m o l . d m}^{-3}\right)$} \\
\hline open & $0-10$ & 1 & 29 & 3.6 & 1250 & 0.5 & 2 & 1 & 58 & 11.9 \\
\hline open & $10-20$ & 1 & 21 & 3.7 & 1000 & 1.2 & 1 & 1 & 52 & 10.5 \\
\hline shaded & $0-10$ & 1 & 38 & 3.5 & 1500 & 1.0 & 2 & 1 & 84 & 15.4 \\
\hline shaded & $10-20$ & 10 & 30 & 3.6 & 1525 & 4.6 & 1 & 1 & 75 & 15.0 \\
\hline
\end{tabular}

Observations: $\mathrm{OM}=$ organic matter; $\mathrm{H}+\mathrm{Al}=$ potential acidity.

TABLE 2

\begin{tabular}{|c|c|c|}
\hline Assay & Exhumation date & Burial time (days) \\
\hline I & June, $27^{\text {th }} 2001$ & 32 \\
\hline II & July, $31^{\text {st }}$ & 66 \\
\hline III & September, $03^{\text {rd }}$ & 99 \\
\hline IV & October, $04^{\text {th }}$ & 130 \\
\hline $\mathrm{V}$ & November, $05^{\text {th }}$ & 161 \\
\hline VI & December, $06^{\text {th }}$ & 192 \\
\hline VII & January, $04^{\text {th }} 2002$ & 220 \\
\hline VIII & February, $01^{\text {st }}$ & 247 \\
\hline IX & March, $05^{\text {th }}$ & 281 \\
\hline $\mathrm{X}$ & April, $02^{\text {nd }}$ & 308 \\
\hline
\end{tabular}


Germination assays were conducted in climatized rooms under continuous cool white fluorescent light (photon flux density of PAR $\cong 34.4 \mu \mathrm{mol} . \mathrm{s}^{-1} . \mathrm{m}^{2}$ ) at $26 \pm 2{ }^{\circ} \mathrm{C}$, in $9 \mathrm{~cm}$ glass Petri dishes lined with three layers of filter paper moistened with distilled water. Prior to the germination tests, the seeds were surface disinfected with a $10 \%$ commercial sodium hypochloride solution, then washed in distilled water. Ten assays were conducted and the germination of both dry stored and exhumed seeds was checked for 95 days. The radicle protrusion was used as criterion for seed germination.

Germination percentages were transformed into angular values and the means compared by ANOVA at 0.05 probability (Sokal \& Rohlf, 1995). Average germination times $(t)$ were determined according to Labouriau (1983), from the equation: $t=\Sigma\left(\mathrm{n}_{\mathrm{i}} \cdot \mathrm{t}_{\mathrm{i}}\right) . \Sigma \mathrm{n}_{\mathrm{i}}^{-1}$, where $\mathrm{n}_{\mathrm{i}}=$ number of seeds germinated at the time interval $t_{i}$.

\section{RESULTS}

Frequency distribution of grouped data of individual Psichotria vellosiana seed fresh weight did not differ from the respective adjusted normal data (K-S test) showing that no segregated subpopulations were encountered, and the fresh weight variation among the seeds could be ascribed to chance. Nevertheless, a slight negative asymmetry of the frequencies distribution was observed (Table 3), showing that seed fresh weights are concentrated in the left of the mode. The seed water content (fresh weight basis) prior to the beginning of the assays was $11.1 \%$. Imbibition of intact and scarified seeds showed a similar pattern, with a rapid initial absorption of up to $24 \mathrm{~h}$ followed by a slower imbibition rate from $24 \mathrm{~h}$ to $96 \mathrm{~h}$ then attaining a lag phase with values between $15 \%$ and 20\% (Fig. 1).

TABLE 3

Some characteristics of the Psychotria vellosiana seeds. Data (mean $\pm \mathrm{SE})$ from individual seeds $(\mathrm{N}=100)$.

\begin{tabular}{|l|l|}
\hline Fresh Weight $\mathbf{( g )}$ & \\
\hline \multicolumn{1}{|c|}{ Mean } & $0.009 \pm 0.0004$ \\
\hline Skewness & -0.486 \\
\hline \multicolumn{1}{|c|}{ Kurtosis } & -0.166 \\
\hline Dry Weight $(\mathbf{g})$ & $0.008 \pm 0.0004$ \\
\hline Water content $\mathbf{( \% , F W}$ basis) & $11.1 \pm 0.24$ \\
\hline Width $(\mathbf{c m})$ & $0.26 \pm 0.007$ \\
\hline Lenght $(\mathbf{c m})$ & $0.36 \pm 0.01$ \\
\hline
\end{tabular}

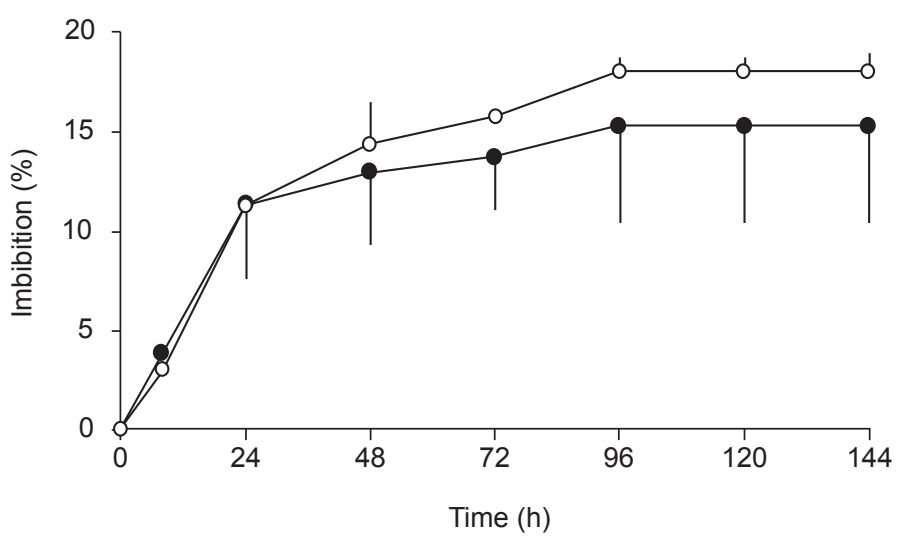

Fig. 1 - Percentage of water uptake (mean \pm SE) by intact (dark circles) and scarified (open circles) Psychotria vellosiana seeds. 
Newly collected Psychotria vellosiana seeds germinated better under white light than in darkness $(\mathrm{F}=8.52 ; \mathrm{p}=0.019)$, although the germinability had been less than $15 \%$ after 135 days incubation at $25{ }^{\circ} \mathrm{C}$. Thereafter, the germination assays were performed under white light.

Fig. 2 shows the effect of the exhumation date on the germination of exhumed seeds from both different sites (whether open or shaded) and depths $(5 \mathrm{~cm}$ or $15 \mathrm{~cm})$. In general, there was a reduction in seed germination with storage time both in soil and laboratory conditions (Fig. 2). Moreover, the burial depth had little effect on the germination of $P$. vellosiana seeds in controlled conditions and the only significant difference $(\mathrm{F}=2.14 ; \mathrm{P}=0.031)$
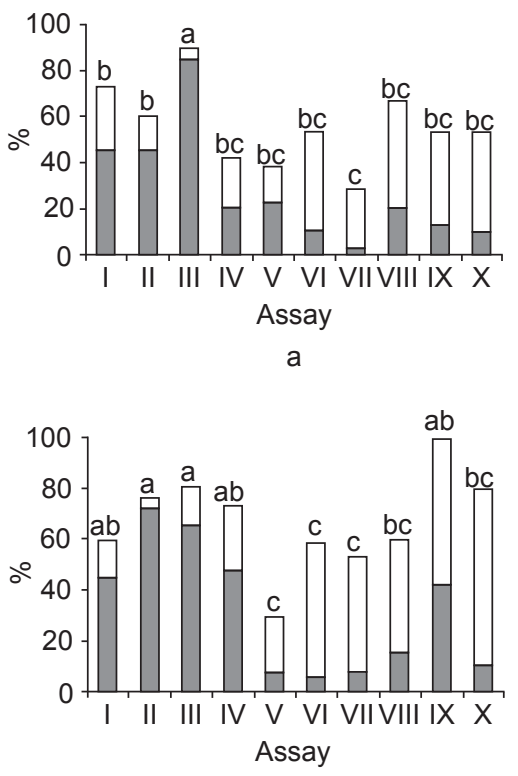

c

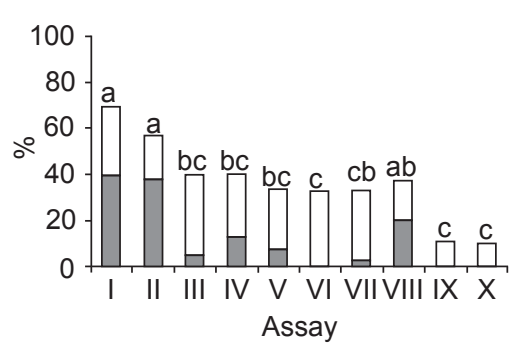

e was observed at assay IX, where seeds retrieved from $5 \mathrm{~cm}$ germinated at a higher percentage as compared to $15 \mathrm{~cm}$ depth (analysis not shown). The environment (whether shaded or open site) also had a small effect on the germination, with a higher proportion of germinating seeds exhumed from shaded than open sites in assays IV and VII.

The germination of dry-stored seeds was around $40 \%$ in assays I and II decreasing to values lower than $12 \%$ from 99 days storage, with the exception of assay VIII where germination attained $19 \%$. No seeds germinated in assays VI, IX and X (Fig. 2e). Dry stored seeds tended to germinate at lower levels than exhumed ones, with the exception
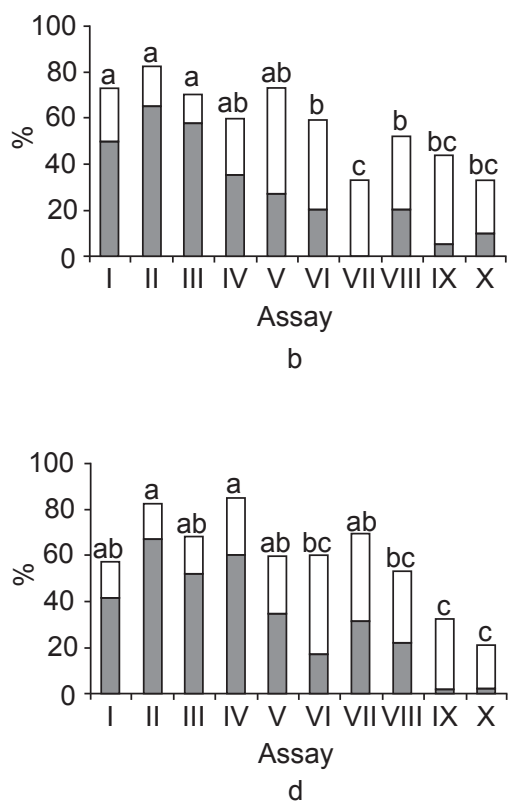

Fig. 2 - Germination percentage (hatched bar) and viability (open bar) of soil-stored and dry-stored Psychotria vellosiana seeds after different time of storage (see Material and Methods for details). a) seeds stored in cerrado soil at $5 \mathrm{~cm}$ depth in open site; b) seeds stored in cerrado soil at $15 \mathrm{~cm}$ depth in open site; c) seeds stored in cerrado soil at $5 \mathrm{~cm}$ depth in shaded site; d) seeds stored in cerrado soil at $15 \mathrm{~cm}$ depth in shaded site; and e) seeds dry-stored at room temperature. Germination was checked for 95 days. Small letters $(\mathrm{p}=0.05)$ compare germination amongst different assays. 
of assays I, II, V, VII and VIII where germinabilities were similar.

The average germination time was found to be heterogeneous and highly variable within treatments, thus few or no differences could be observed amongst the germination rate of exhumed seeds either from different depths or sites. Otherwise in some assays where germination did occur, exhumed seeds germinated faster than dry stored ones (Table 4). Germination of exhumed seeds started from 8 to 88 days (arithmetical mean, $\mathrm{x}=29$ days) after seeds had imbibed, while dry-stored seeds took between 15 and 88 days $(\mathrm{x}=45$ days) for radicle protrusion (data not shown).

A Tetrazolium test was done on the ungerminated seeds remaining after germination to assess their viability percentage. The graphs (Fig. 2) show the overall viability percentage, that is, the viable (tetrazolium test) plus germinated seeds divided by the amount of seeds put in the Petri dishes. We observed that there was no appreciable loss of seed viability having burial time during the study period, except for the seeds exhumed from $15 \mathrm{~cm}$ depth at shaded sites (Fig. 2d). In general, the soil storage treatments did not affect seed viability when compared to each other; however the soil storage favoured seed viability as compared to dry stored seeds. The relatively high number of exhumed ungerminated viable seeds at the end of each assay, mainly in assays $\mathrm{V}$ to $\mathrm{X}$, suggests that seeds show dormancy and require an extended time to germinate (more than 95 days). There was a decrease in the percentage of ungerminated viable seeds stored at room conditions with storage time in assays I to III, they were then kept unchanged from assays III to VIII, and dropped to values lower than $10 \%$ in assays IX and X. Otherwise the germination percentage dropped soon after assay II and stayed low from III to X, with the exception of the assay VIII (Fig. 2e).

When seeds were exhumed, the number of Psychotria vellosiana seedlings within the nylon envelopes were recorded (germination in situ). We observed that some seeds had germinated from approximately 100 days after burial. The percentage of germinated seeds in situ was variable, with two or more germination peaks distributed throughout the burial time, but a general trend was observed that the number of seedlings increased with burial time from 130 days storage (Fig. 3). We did not observe significant differences between environment and burial depth treatments; otherwise we found that the germination of buried seeds tended to increase with rainfall.

\section{DISCUSSION}

The degree of seed tolerance to low moisture levels or temperatures varies with species, but is grouped in three general categories: orthodox; intermediate and recalcitrant. Orthodox seeds maintain their viability at relatively low water contents (3-12\%, dry weight basis) whereas recalcitrant seeds cannot withstand drying and must retain a relatively high moisture content $(35-80 \%)$ in order to maintain viability. The seed water content of the Psychotria vellosiana seeds

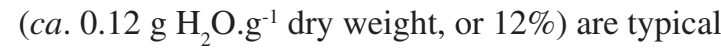
of intermediate seeds, whose "optimum" seed moisture content to improve seed longevity ranges from $9 \%$ to $13 \%$, approximately. Although such water content is relatively low for a non-pioneer

TABLE 4

Average germination time $( \pm \mathrm{SE})$ for the germination of exhumed and dry-stored Psychotria vellosiana seeds.

\begin{tabular}{|l|l|l|l|l|l|l|l|l|l|l|}
\cline { 2 - 11 } \multicolumn{1}{c|}{} & \multicolumn{10}{c|}{ Assay } \\
\cline { 2 - 12 } \multicolumn{1}{c|}{} & \multicolumn{1}{c|}{ I } & \multicolumn{1}{c|}{ II } & \multicolumn{1}{c|}{ III } & IV & V & VI & VII & VIII & IX & X \\
\hline Open 5 & $38 \pm 7$ & $40 \pm 11$ & $31 \pm 17$ & $34 \pm 11$ & $30 \pm 4$ & $30 \pm 2$ & $39 \pm 1$ & $88 \pm 1$ & $44 \pm 1$ & $29 \pm 2$ \\
\hline Open 15 & $42 \pm 12$ & $29 \pm 8$ & $35 \pm 14$ & $22 \pm 4$ & $31 \pm 11$ & $22 \pm 3$ & 0 & $85 \pm 5$ & $56 \pm 1$ & $41 \pm 2$ \\
\hline Shaded 5 & $39 \pm 8$ & $35 \pm 12$ & $32 \pm 9$ & $26 \pm 8$ & $27 \pm 3$ & $26 \pm 1$ & $32 \pm 1$ & $84 \pm 9$ & $50 \pm 22$ & $61 \pm 1$ \\
\hline Shaded 15 & $38 \pm 9$ & $31 \pm 11$ & $37 \pm 15$ & $31 \pm 8$ & $40 \pm 8$ & $28 \pm 8$ & $28 \pm 3$ & $71 \pm 19$ & $77 \pm 1$ & $56 \pm 1$ \\
\hline Dry & $51 \pm 7$ & $46 \pm 6$ & $64 \pm 1$ & $65 \pm 5$ & $52 \pm 1$ & 0 & $53 \pm 1$ & $88 \pm 1$ & 0 & 0 \\
\hline
\end{tabular}

Observations: Open $=$ seeds exhumed from open site; Shaded $=$ seeds exhumed from shaded site; $5=$ seeds exhumed from $5 \mathrm{~cm}$ depth; 15 = seeds exhumed from $15 \mathrm{~cm}$ depth; Dry $=$ dry stored seeds. 

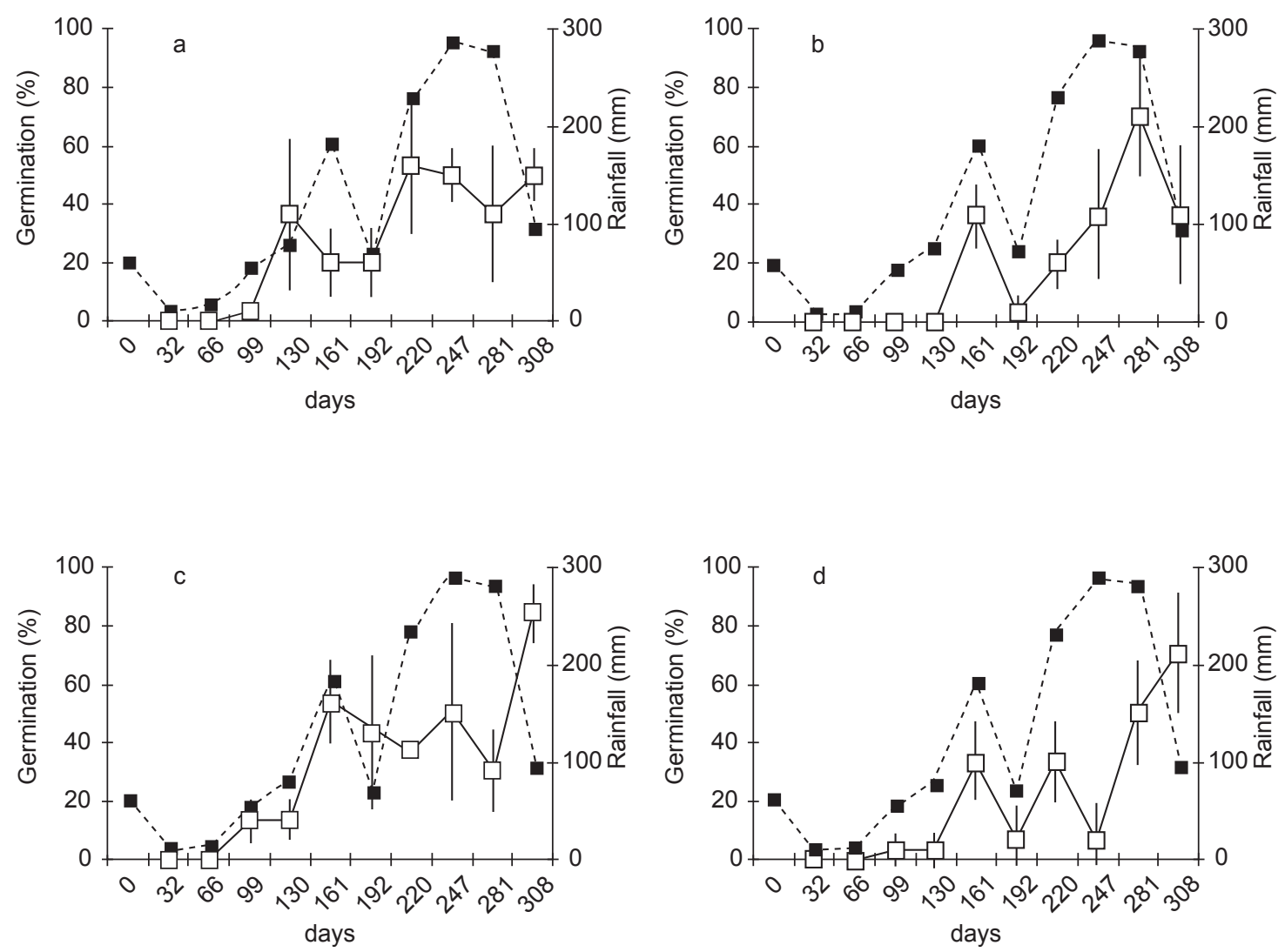

Fig. 3 - Germination in situ (mean \pm SE) of P. vellosiana seeds after different storage times. a) seeds buried at $5 \mathrm{~cm}$ depth in open site; b) seeds buried at $15 \mathrm{~cm}$ depth in open site; c) seeds buried at $5 \mathrm{~cm}$ depth in shaded site; d) seeds buried at $15 \mathrm{~cm}$ depth in shaded site. Dark symbols = rainfall $(\mathrm{mm})$; open symbols = germination $(\%)$.

species (Garwood, 1989), it enables P. vellosiana seeds to withstand a water deficit since mature seeds are shed at the beginning of the dry season. Taking into account the fresh weight distribution of the Psychotria vellosiana seed samples, the population was homogeneous as to such character, and no sub-populations could be found. Thus, seed fresh weight variation could not account for variations of the seed behavior in the germination assays. The water imbibition by $P$. vellosiana seeds after $144 \mathrm{~h}$ was relatively low as compared to other seeds such as Vicia sativa (112\%) and Hyptis suaveolens $(50 \%)$ (Mayer \& PoljakoffMayber, 1989; Felippe et al., 1983). As reported for Sida rhombifolia seeds (Cardoso, 1990), such a low imbibition rate was probably not caused by preventing water entry into the seeds as shown by the water uptake of intact and scarified seeds.
The germination of Psychotria vellosiana seeds declined with increasing time of storage both in cerrado soil and room conditions, with few differences being observed between burial treatments. Similar results were obtained by Sassaki et al. (1999), who stored Psychotria barbiflora fruit in cerrado soil for up to 7 months and reported that, the longer the period of storage in soil the lower the germination of exhumed seeds, with a decrease of seed viability. In exhumed Psychotria vellosiana seeds from $5 \mathrm{~cm}$ depth both in an open and shaded environment, the decrease of the seed germination was not accompanied by a reduction in the seed viability, whereas in seeds retrieved from $15 \mathrm{~cm}$ depth, both viability and germination decreased with storage time, although viability diminished less sharply as compared to germination. Such results differ from Acacia tortilis 
and Dichrostachys cinerea, two woody legumes from the African savanna, of which viability tended to increase with the depth of burial (Witkowsky \& Garner, 2000). These results suggest that part of the seeds may be dormant or requires an extended time to germinate. Such behavior was different from Parthenium hysterophorus (Asteraceae) seeds whose germination is enhanced after 1 month of seed burial in the soil as compared to freshly harvested seeds (Tamado et al., 2002). The authors concluded that Parthenium hysterophorus has seeds that are initially dormant and dormancy in buried seeds is reduced by both biotic and non-biotic factors operating in the soil. When a true dormancy mechanism is operating the seed germination is arrested even in the presence of optimal or adequate germination conditions. Although more detailed studies are needed, probably that was not the case of Psychotria vellosiana, whose seeds germinate slowly provided that the environment is suitable. According to Paz et al. (1999), the germination of some species of the genus Psychotria was found to be slow, with total seedling emergence occurring only 3-5 months after seeds were sown under controlled greenhouse conditions. With few exceptions, germination percentage and germination rate of exhumed seeds were highly variable and the burial treatments did not differ to each other, however differences could be observed between field-buried and dry-stored seeds in some assays, with burial favouring the germination. Such results are compatible with Paz et al. (1999) who reported that the germination of the tree species, Psychotria limonensis and Psychotria simiarum sowed in the field in a tropical rain forest was similar in gaps and shaded habitats. A reason for the higher germination of exhumed seeds may be that they were partially hydrated in the cerrado soil as shown by Sassaki et al. (1999) who reported that the water content of Psychotria barbiflora seeds was higher $(11-17 \%)$ in seeds stored in cerrado soil than the seeds dry-stored at $4{ }^{\circ} \mathrm{C}$. The moisture levels of the soil stored Psychotria barbiflora seeds $(11-17 \%)$ were similar to the Psychotria vellosiana seeds soaked in distilled water $(15 \%$ 20\%). The germination assays and the tetrazolium tests showed that Psychotria vellosiana seeds remained partially viable after 10 months of storage both at room conditions and in the soil, similarly to
Palicourea rigida whose seeds remained viable for a year in the soil (Garcia-Nunez et al., 2001).

The proportion of Psychotria vellosiana seedlings within the seed envelopes exhumed after different burial time was erratic, though it tended to be higher in the "rainy" months. Unlike P. vellosiana, artificially buried seeds of Palicourea rigida remained viable without germinating until 10 months later when all germinated synchronously at the beginning of the following rainy season (Garcia-Nunez et al., 2001). These results suggest that germination of $P$. vellosiana seeds in situ is affected by water availability, and that absence of light may not limit the germination of buried seeds, although germination was encouraged by white light under controlled laboratory conditions. As observed for Palicourea marcagravii and Psychotria hoffmansegiana (Araujo \& Cardoso, unpublished) the burial site had little or no effect on the germination in situ of Psychotria vellosiana seeds.

Given that germination of dry stored Psychotria vellosiana seeds started 15 days from imbibition while germination in situ was observed only after 3 months of burial, we concluded that water availability in the soil might be a limiting factor for a successful germination of $P$. vellosiana in the field, and the seeds may constitute a persistent soil seed bank in the cerrado soil as dispersed seeds remain viable in the soil until the following period of seed dispersal. Otherwise, a question remains as to whether $P$. vellosiana seeds show true dormancy when dispersed or the seeds simply remain quiescent in the soil and germinate during the main rainy season. Oliveira (1998) reported that cerrado woody species dispersed by animals have dormancy mechanisms that delay the germination until favourable conditions are present. If dormant, $P$. vellosiana seeds would show physiological, morphological or morpho-physiological physical dormancy rather than physical (coat imposed dormancy). The strategy of $P$. vellosiana seeds may also be one of the parts of potentially continuous germination if environmental conditions (namely moisture and temperature) are not limiting, as shown by Artemisia frigida seeds (Bay \& Romo, 1994).

Acknowledgments - The authors thank Conselho Nacional de Desenvolvimento Científico e Tecnológico-CNPq, for financial support (Proc. 475470/2001-0) and the research fellowship 
(Proc. 300901/03-8). Thanks are also due to Wenilton L. Daltro for the graphs.

\section{REFERENCES}

BAI, Y. \& ROMO, J. T., 1994, Germination of previously buried seeds of fringed sage (Artemisia frigida). Weed Sci., 42: 390-397.

BARRoSO, G. M., MORIM, M. P, PEIXOTO, A. L. \& ICHASO, C. L. F., 1999, Frutos e Sementes: Morfologia Aplicada à Sistemática de Dicotiledôneas. Editora UFV, Viçosa, 443p.

BASKIN, J. M. \& BASKIN, C. C., 1998, Seeds: Ecology, Biogeography, and Evolution of Dormancy and Germination. Academic Press, San Diego, Cap. 3, pp. 20-47.

BEWLEY, J. D. \& BLACK, M., 1994, Seeds: Physiology of development and germination. Plenum Press, New York, $445 \mathrm{p}$.

CARDOSO, V. J. M., 1990, Germination studies on dispersal units of Sida rhombifolia L. Revta. Brasil. Bot. 13: 83-88.

CESAR, O., PAGANO, S. N., LEITÃO FILHO, H., MONTEIRO, R., SILVA, O. A., MARINIS, G. \& SHEPHERD, G. J., 1988, Estrutura Fitossociológica do estrato Arbóreo de uma Área de Vegetação de cerrado no município de Corumbataí (Estado de São Paulo). Naturalia, 13: 91-101.

FELIPPE, G. M., POLO, M., CARDOSO, V. J. M. \& FIGUEIREDO-RIBEIRO, R. C. L., 1983, Germinação da unidade de dispersao da erva invasora Hyptis suaveolens. An. Sem.Reg. Ecol. III, São Carlos: 245-261.

FERRI, M. G., 1977, Ecologia dos Cerrados. IV Simposio Sobre o Cerrado, pp. 15-36.

GARCIA-NUNEZ, C., AZÓCAR, A. \& SILVA, J. F., 2001, Seed production and soil seed bank in three evergreen woody species from a neotropical savanna. J. Trop. Ecol, 17: 563-576.
GARWOOD, N. C., 1989, Tropical Soil Seed Banks; A Review, pp. 221-230. In: M.A.LECK (ed.), Ecology of Soil Seed Banks. Academic Press, San Diego.

LABOURIAU, L. G., 1983, A Germinação das Sementes. Secretaria Geral da Organização dos Estados Americanos, Washington, 174p.

LABOURIAU, L. G., VALIO, I. F. M. \& HERINGER, E. P., 1964, Sobre o sistema reprodutivo de plantas dos Cerrados - I. An. Acad. Brasil. Cienc., 36: 449-464.

MAYER, A. M. \& POLJAKOFF-MAYBER, A., 1989, The Germination of Seeds, 4. Ed. Pergamon Press, Oxford, $269 \mathrm{p}$.

OLIVEIRA, P. E., 1998, Fenologia e biologia reprodutiva das espécies de Cerrado, pp 169-192. In: S. M. SANO \& S.P. ALMEIDA (eds.), Cerrado: Ambiente e Flora. Embrapa, Planaltina.

PAZ, H., MAZER, S. J. \& MARTINEZ-RAMOS, M., 1999, Seed mass, seedling emergence and environmental factors in seven rain forest Psychotria (RUBIACEAE). Ecology, 80: $1594-1606$.

RATTER, J., RIBEIRO, J. F. \& BRIDGEWATER, S., 1997, The brazilian cerrado vegetation and threats to its biodiversity. Ann. Bot., 80: 223-230.

SASSAKI, R. M., RONDON, J. N., ZAIDAN, L. B. \& FELLIPE, G. M., 1999, Germination of seeds from herbaceous plants artificially stored in cerrado soil. Rev. Brasil. Biol., 21: 271279.

SOKAL, R. R. \& ROHLF, F. J., 1995, Biometry, $3^{\text {a }}$ Ed. W.H. Freeman and Co., New York, 887p.

TAMADO, T., SCHUTS, W. \& MILBERG, P., 2002, Germination ecology of the weed Parthenium hysterophorus in eastern Ethiopia. Ann. Appl. Biol., 140: 263-270.

WITKOWSKI, E. T. F. \& GARNER, R. D., 2000, Spatial distribution of soil seed banks of three African savanna woody species at two contrasting sites. Plant Ecol., 149: 91-106. 